\title{
PENGARUH PENGANGGURAN TERBUKA TERDIDIK UNIVERSITAS TERHADAP GARIS KEMISKINAN DI PROVINSI ACEH
}

\author{
Sri Wahyuni ${ }^{1)}$ \\ 1) 2) Fakultas Ekonomi, Universitas Almuslim \\ Email:wahyuni1313@gmail.com
}

\begin{abstract}
Penelitian ini bertujuan untuk menganalisis pengaruh pengangguran terbuka universitas wanita dan laki-
laki terhadap garis kemiskinan di Provinsi Aceh dengan menggunakan data dari Badan Pusat Statistik
Aceh periode 2012-2020. Selanjutnya, data dianalisis dengan menggunakan metode analisis regresi linear
berganda dan diolah dengan menggunakan SPSS (Statistical Product and Service Solutions). Penelitian
ini menemukan bahwa pengangguran terbuka laki laki berpengaruh positif terhadap garis kemiskinan
meskipun perkembangan pengangguran terdidik universitas laki laki lebih rendah dibandingkan
pengangguran terdidik universitas wanita di Provinsi Aceh. Sedangkan pengangguran terbuka terdidik
universitas wanita tidak berpengaruh terhadap garis kemiskinan yang terjadi di Provinsi Aceh. Kebijakan
yang perlu diperhatikan oleh pemerintah daerah Aceh adalah menyediakan lapangan pekerjaan bagi
terdidik universitas laki-laki dan Perguruan Tinggi khususnya di Provinsi Aceh dapat melahirkan lulusan
yang siap pakai di dunia kerja.
Kata Kunci : Pengangguran Terbuka Terdidik Universitas Wanita, Pengangguran Terbuka Terdidik
Universitas Laki-Laki, Garis Kemiskinan
\end{abstract}
\section{Pendahuluan}

Tahun 2020, tingkat kemiskinan di Provinsi Aceh menjadi sorotan karena menjadi provinsi termiskin di Sumatera dimana mencapai 15,43\% (bertambah 19.000 orang penduduk miskin) yang merupakan persentase tingkat kemiskinan tertinggi untuk provinsi provinsi yang berada di kawasan pulau Sumatera. Tingkat keparahan kemiskinan yang ditetapkan oleh Badan Pusat Statistik yaitu ketimpangan pengeluaran diantara penduduk miskin (https://aceh.bps.go.id). Hal ini diperburuk dengan pandemik Corona Virus Disease (covid-19), dimana pemerintah menerapkan kebijakan kebijakan pencegahan penyebaran covid-19. Kebijakan kebijakan ini secara langsung maupun tidak langsung telah memberikan dampak kepada masyarakat Aceh yaitu lambannya perputaran perekonomian di Aceh akibat terhentinya beberapa aktivitas perkantoran, sekolah dan lesunya Usaha Mikro Kecil Menengah (UMKM). Kebijakan ini juga memberikan dampak meningkatnya jumlah pengangguran di provinsi Aceh.

Tingkat pengangguran merupakan salah satu isu utama dalam ekonomi makro, terutama pengangguran terdidik. Pengangguran terdidik khusus lulusan universitas merupakan pengangguran friksional yaitu lulusan yang sedang mencari pekerjaan. Sesuai dengan pendapat Fitri dan Junaidi (2016) yang menyatakan bahwa pengangguran yang terjadi selama lulusan mengalami masa tunggu sampai menemukan pekerjaan. Tantangan ditengah ketidakpastian pandemik covid-19, menurut Sekretaris Jenderal Kementerian Tenaga Kerja menyatakan bahwa angka pengangguran terdidik terus bertambah bahkan terbilang tinggi sehingga perlu respon adanya kebijakan dalam penyediaan lapangan pekerjaan (Kementerian Ketenagakerjaan RI, 2021). Pandemik covid-19 telah menyebabkan terjadinya ketidakseimbangan antara permintaan dan penawaran tenaga kerja dimana permintaan terhadap tenaga kerja sedikit bahkan banyak terjadi pemutusan hubungan kerja dan banyak industri yang tutup. Pemutusan hubungan kerja ini memperbanyak pengangguran terdidik khususnya lulusan terukur (Permatasari dkk., 2021). Menurut Badan Pusat Statistik tingkat pengangguran terbuka (TPT) adalah persentase jumlah pengangguran terhadap jumlah angkatan kerja. 
kerjauniversitas.

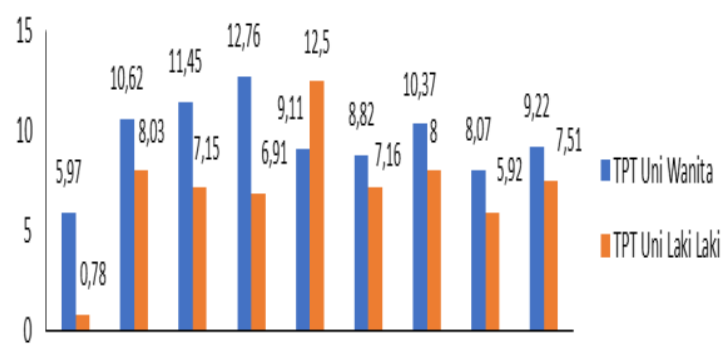

$2012 \quad 2013 \quad 201420152016 \quad 2017 \quad 2018 \quad 20192020$

Gambar 1 Perkembangan TPT Terdidik Universitas Provinsi Aceh

Sumber: Data Olahan

Gambar 1.1 menyajikan perkembangan tingkat pengangguran terbuka terdidik Universitas wanita lebih besar dibandingkan tingkat pengangguran terbuka laki-laki di Provinsi Aceh. Masih menjadi polemik di Provinsi Aceh bahwa wanita lebih baik melakukan pekerjaan rumah tangga dibandingkan bekerja. Sesuai dengan penelitian Astina (2019) yang menyimpulkan bahwa keputusan wanita aceh bekerja masih didasari mengurus pekerjaan domestik daripada mengembangkan kapasitas diri di luar rumah. Sedangkan laki-laki memang sudah berkewajiban untuk bekerja.

Berdasarkan fenomena di atas maka tujuan penelitian ini adalah menganalisis pengaruh pengangguran terbuka terdidik universitas wanita dan laki-laki terhadap garis kemiskinan di Provinsi Aceh. Temuan dari penelitian ini diharapkan dapat menjadi acuan bagi pemerintah daerah Aceh dalam membuat kebijakan yang berkaitan dengan pengentasan kemiskinan terutama dalam penyediaan lapangan pekerjaan di Provinsi Aceh.

\section{Kajian Teoritis}

Pengangguran

Seseorang dikatakan pengangguran (usia produktif) apabila memenuhi salah satu dari tiga standar yang telah ditetapkan oleh International Labour Organization (ILO, 2003), yaitu:

1) "tanpa pekerjaan", yaitu tidak berada dalam pekerjaan berbayar atau wirausaha sebagaimana ditentukan oleh definisi ketenagakerjaan internasional;

2) "saat ini tersedia untuk bekerja", yaitu tersedia untuk pekerjaan berbayar atau wirausaha selama periode referensi; dan

3) "mencari pekerjaan", yaitu telah mengambil langkah-langkah spesifik dalam periode tertentu baru-baru ini untuk mencari pekerjaan berbayar atau wirausaha.

Kim (2018) menyatakan bahwa pengangguran disebabkan pada permintaan tenaga kerja yang kurang atau ketidakcocokan pekerjaan. Pengangguran tanpa permintaan adalah ketika jumlah pekerjaan benar-benar tidak mencukupi dibandingkan dengan jumlah pengangguran atau dengan kata lain pengangguran terjadi dimana lowongan pekerjaan baru terisi secara instan. Sedangkan ketidaksesuaian pengangguran terjadi ketika lapangan pekerjaan dan pengangguran hidup berdampingan atau dengan kata lain pekerjaan kosong tidak terisi. $\mathrm{Di}$ antara jenis pengangguran yang disebabkan oleh ketidaksesuaian, yang dapat diselesaikan melalui mobilitas antar industri dari pekerja yang menganggur didefinisikan sebagai "pengangguran ketidaksesuaian tingkat industri" dan lainnya sebagai "pengangguran ketidaksesuaian (struktur usia) lainnya". Ketidaksesuaian tingkat industri pengangguran: Jika tidak ada faktor gesekan dalam perekonomian, lapangan pekerjaan dapat diisi oleh pekerja pengangguran yang berpindah lintas industri, sehingga mengurangi pengangguran. Faktor friksi termasuk kekakuan upah dan kondisi kerja, kurangnya dan distorsi informasi, biaya mobilitas fisik atau implisit, dll. Hal ini disebabkan misalnya, masuknya pengangguran ke industri tertentu mungkin dibatasi oleh upah rendah, dll, meskipun jumlah lapangan pekerjaan yang tinggi. Ketidakcocokan pengangguran (struktur usia) lainnya: Pengangguran yang tidak sesuai tidak dapat dikurangi dengan pengangguran yang berpindah-pindah industri. $\mathrm{Hal}$ ini disebabkan oleh faktor non-industri dan ketidaksesuaian lainnya yang timbul dari proses pencocokan (proses perekrutan dan pencarian kerja) antara pekerjaan yang kosong dan pekerja yang menganggur. Misalnya, lapangan pekerjaan tetap tidak terisi karena perbedaan karakteristik yaitu usia. Selain itu, lapangan pekerjaan dan pekerja yang menganggur tetap tidak tertandingi untuk jangka waktu yang cukup lama karena kesenjangan waktu antara pembukaan pekerjaan hingga perekrutan aktual yang disebabkan oleh faktor kelembagaan dan teknis.

Tingkat pengangguran terbuka adalah nilai yang menunjukkan jumlah penduduk usia kerja yang sedang mencari pekerjaan, sedang mempersiapkan usaha, merasa tidak mungkin mendapatkan pekerjaan atau sudah mempunyai pekerjaan tetapi belum mulai bekerja dan sering digunakan untuk pekerjaan. 
Pengangguran memiliki keterkaitan dengan variabel lainnya seperti pendidikan. Menurut Prasanti dkk., (2015) pendidikan sangat menentukan tingkat produktivitas seseorang dalam bekerja dimana semakin tinggi tamatan pendidikan seseorang maka semakin tinggi pula kemampuan kerja atau produktivitas sesorang dalam bekerja dengan asumsi lapangan pekerjaan formal tersedia maka tingkat pendidikan diharapkan dapat mengurangi jumlah pengangguran. Selaras dengan Sari (2013) yang menyatakan bahwa antara perencanaan pembangunan pendidikan dengan perkembangan lapangan kerja tidak selaras dimana lembaga pendidikan di Indonesia hanya menghasilkan lulusan pencari kerja, bukan pencipta kerja. untuk mencapai lulusan pencipta kerja maka perlu tambahan keterampilan di luar bidang akademik yang harus dikuasai.

\section{Garis Kemiskinan}

Kemiskinan masih menjadi masalah di Indonesia khususnya di Provinsi Aceh karena masih ada sekelompok anggota masyarakat yang tidak dapat memenuhi kebutuhan pokoknya sehari hari. Faktor faktor penyebab terjadinya kemiskinan sangat beragam. Dalam penelitian Nurwati (2008) menyatakan bahwa kemiskinan dapat dibagi dalam dua kategori yaitu dari sudut pandang pengukuran yang terdiri dari kemiskinan absolut dan relatif, dan sudut pandang penyebab dikelompokkan menjadi kemiskinan alamiah dan strutkural. Selain itu Soleh (2018) menyatakan bahwa kemiskinan absolut merupakan pendapatan seseorang yang tidak dapat memenuhi kebutuhan dasar minimum untuk mencapai hidup layak, dan kemiskinan relatif dapat dijelaskan melalui distribusi pendapatan masyarakat yang tidak merata dimana masih terdapat pendapatan yang lebih rendah meskipun sudah mampu memenuhi kebutuhan dasar minimum. Selanjutnya Yacoub (2012) menambahkan bahwa kemiskinan dapat menyebabkan dapat menjadi penentu dan faktor dominan yang mempengaruhi persoalan kemanusiaan seperti keterbelakangan, kebodohan, ketelantaran, kriminalitas, kekerasan, perdagangan manusia, buta huruf, putus sekolah, anak jalanan, pekerja anak.

$$
\text { Swaramarinda (2014) dalam }
$$

penelitiannya menyatakan bahwa ukuran garis kemiskinan merupakan tahap penting dalam mengukur skala kemiskinan suatu wilayah atau negara, namun variabel variabel yang diukur mengalami perubahan seiring waktu berjalan. Di Indonesia untuk skala kemiskinan diukur melalui garis kemiskinan dimana konsep garis kemiskinan menurut Badan Pusat Statistik adalah

1. Garis Kemiskinan (GK) merupakan penjumlahan dari Garis Kemiskinan Makanan (GKM) dan Garis Kemiskinan Non Makanan (GKNM). Penduduk yang memiliki rata-rata pengeluaran perkapita per bulan dibawah Garis Kemiskinan dikategorikan sebagai penduduk miskin.

2. Garis Kemiskinan Makanan (GKM) merupakan nilai pengeluaran kebutuhan minimum makanan yang disetarakan dengan 2100 kilokalori perkapita perhari. Paket komoditi kebutuhan dasar makanan diwakili oleh 52 jenis komoditi (padi-padian, umbi-umbian, ikan, daging, telur dan susu, sayuran, kacang-kacangan, buah-buahan, minyak dan lemak, dll)

3. Garis Kemiskinan Non Makanan (GKNM) adalah kebutuhan minimum untuk perumahan, sandang, pendidikan dan kesehatan. Paket komoditi kebutuhan dasar non makanan diwakili oleh 51 jenis komoditi di perkotaan dan 47 jenis komoditi di pedesaan.

\section{Metodelogi}

Data yang digunakan dalam penelitian ini adalah data sekunder yang diperoleh dari Badan Pusat Statistik Aceh periode 2012-2020. Metode yang digunakan dalam penelitian ini adalah metode kuantitatif dimana data dianalisis dengan menggunakan metode analisis regresi linear berganda dan diolah dengan menggunakan SPSS (Statistical Product and Service Solutions).

$$
\operatorname{Ln} Y_{t}=\beta_{0}+\beta_{1} \operatorname{Ln} X_{1 t}+\beta_{2} \operatorname{LnX} X_{2 t}+\varepsilon
$$

Keterangan:

$Y_{t} \quad=$ Tingkat Garis Kemiskinan

$X_{1 t}=$ Tingkat Pengangguran Terbuka

Terdidik Universitas Wanita

$X_{2 t}=$ Tingkat Pengangguran Terbuka

Terdidik Universitas Laki-Laki

$\varepsilon \quad=$ Error term

\section{Hasil dan Pembahasan}

Trend tingkat garis kemiskinan di Provinsi Aceh cenderung meningkat dari waktu ke waktu. Bahkan, Provinsi Aceh pada tahun 2020 menyandang status termiskin di Provinsi Aceh. Kemiskinan merupakan permasalahan penting yang dihadapi oleh Pemerintah Aceh, mengingat Provinsi Aceh adalah Provinsi Aceh yang diberikan otonomi khusus dan mendapatkan dana otonomi khusus (otsus) sejak tahun 2008 sampai dengan 2018 sebanyak Rp. 64,97 trilliun. Dana otsus yang 
diterima sepenuhnya oleh Provinsi Aceh, ternyata belum sepenuhnya dapat mengurangi kemiskinan yang terjadi di Provinsi Aceh (Ananto dkk., 2020)

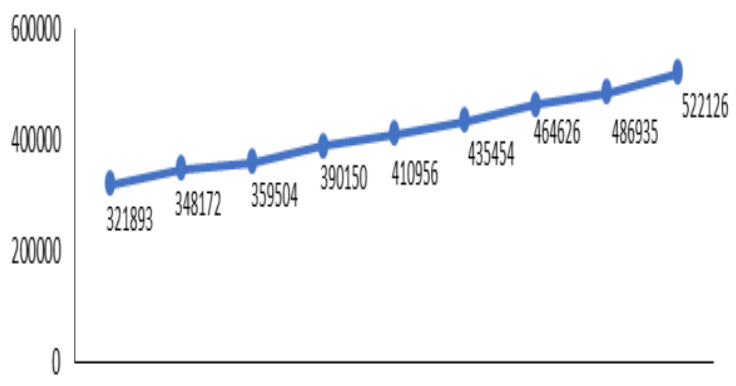

$\begin{array}{lllllllll}2012 & 2013 & 2014 & 2015 & 2016 & 2017 & 2018 & 2019 & 2020\end{array}$

Gambar 2. Perkembangan Tingkat Garis

Kemiskinan di Provinsi Aceh

Sumber: Data Olahan dari tingkat Sekolah Dasar, Sekolah Menengah Pertama, Sekolah Menengah Atas, Sekolah Menengah Kejuruan, Program Diploma dan bahkan Universitas. Selayaknya, Iulusan universitas diharapkan tidak terjadi namun ketidaktersediaan lapangan pekerjaan membuat lulusan terdidik ini menganggur sampai mereka menemukan pekerjaan yang sesuai dengan latar belakang pendidikan mereka. Dengan mengklasifikasikan berdasarkan gender, maka tingkat pengangguran terbuka terdidik universitas lebih banyak wanita dibandingkan laki-laki..

Hasil regresi setelah dilakukan uji Asumsi klasik dan tidak ditemukan adanya autokorelasi, multikolinearitas dan heteroskedastisitas. Hasil regresi adalah:

\begin{tabular}{|c|c|c|c|c|c|c|c|}
\hline \multirow[b]{2}{*}{ Model } & \multicolumn{2}{|c|}{$\begin{array}{c}\text { Unstandardized } \\
\text { Coefficients }\end{array}$} & \multirow{2}{*}{$\begin{array}{c}\text { Standardized } \\
\text { Coefficients } \\
\text { Beta }\end{array}$} & \multirow[b]{2}{*}{$t$} & \multirow[b]{2}{*}{ Sig. } & \multicolumn{2}{|c|}{ Collinearity Statistics } \\
\hline & $\mathrm{B}$ & $\begin{array}{l}\text { Std. } \\
\text { Error }\end{array}$ & & & & Tolerance & VIF \\
\hline 1 (Constant) & 13.971 & .666 & & 20.980 & .000 & & \\
\hline TPT Uni W & -.547 & .320 & -.743 & -1.710 & .138 & .424 & 2.361 \\
\hline TPT Uni LK & .118 & .046 & 1.099 & 2.528 & .045 & .424 & 2.361 \\
\hline$F=3.246$ & & & & & & & \\
\hline $\mathrm{R}=.721$ & & & & & & & \\
\hline $\mathrm{R}^{2}=.520$ & & & & & & & \\
\hline
\end{tabular}

Sumber: Data Olahan

Gambar 5.1 menyajikan tren garis kemiskinan yang cenderung meningkat. Selama satu dasawarsa dana otsus belum mampu menurunkan tingkat kemiskinan yang terjadi di Provinsi Aceh. Pada akhir bulan Maret 2020, pandemik virus corona-19 melanda Indonesia dan Provinsi Aceh juga mengalami dampaknya dimana garis kemiskinan meningkat dari angka 486935 ke angka 522126. Banyak hal yang menyebabkan trend garis kemiskinan diantaranya pendapatan yang tidak mampu memenuhi kebutuhan dasar minimum. Untuk memenuhi kebutuhan dasar minimum ada beberapa kebijakan yang telah dikeluarkan pemerintah yaitu dengan meningkatkan kualitas sumber daya manusia yaitu melalui pendidikan dan pelatihan, serta menciptakan lapangan pekerjaan.

Kebijakan yang telah dibuat juga belum mampu mengurangi tingkat kemiskinan karena masih ditemukan pengangguran terdidik baik
Hasil estimasi regresi ditemukan bahwa tingkat pengangguran laki-laki berpengaruh positif terhadap garis kemiskinan di Provinsi Aceh. Sedangkan tingkat pengangguran terbuka wanita berpengaruh negatif dan tidak signifikan. Temuan ini sangat menarik, dimana diketahui bahwa perkembangan tingkat pengangguran terbuka universitas wanita lebih besar dibandingkan dengan tingkat pengangguran terbuka laki-laki. Tingkat pengangguran terbuka wanita ternyata tidak memberikan dampak terhadap garis kemiskinan. Hal ini memungkinkan terjadi di Provinsi Aceh, dimana wanita umumnya setelah menyelesaikan pendidikan lebih memilih untuk mengurus rumah tangga dibandingkan bekerja di luar. Lain halnya dengan laki-laki di Provinsi Aceh dimana secara aturan norma laki-laki merupakan pencari nafkah, sehingga dituntut untuk bekerja. Secara simultan, tingkat pengangguran terbuka wanita dan laki-laki 
mempengaruhi garis kemiskinan yang ada di Provinsi Aceh.

Ketidakpastian kapan berakhirnya pandemik covid-19 juga menjadi tantangan tersendiri bagi Pemerintah Aceh dalam menurunkan tingkat kemiskinan. Kebijakankebijakan pemerintah dalam mencegah penyebaran covid-19 telah meningkatkan angka pengangguran dimana banyak industri yang ditutup sehingga harus melakukan pemutusan hubungan kerja. Kebijakan social distancing telah memberikan dampak menurunnya pendapatan bagi UMKM. Selain itu, percepatan pemulangan tenaga kerja Indonesia juga menambah tingkat pengangguran. Tenaga kerja Indonesia khusus yang berasal dari Aceh banyak yang bekerja di Malaysia. Seiiring dengan diterapkan lockdown di negara Malaysia maka banyak tenaga kerja Indonesia asal Provinsi Aceh baik yang legal maupun yang illegal pulang ke Aceh. Namun, Pemerintah juga mengeluarkan kebijakankebijakan untuk pemulihan perekonomian selama masa pandemik covid-19 diantaranya memberikan bantuan subsidi kepada UMKM. Namun, kebijakan ini juga belum mampu menurunkan tingkat kemiskinan yang terjadi.

Berdasarkan aturan norma di Provinsi Aceh, maka sangat jelas bahwa laki menjadi pencari nafkah. Meningkatnya jumlah pengangguran terbuka terdidik universitas lakulaki maka dapat meningkatkan garis kemiskinan. Rumah tangga tidak mampu memenuhi kebutuhan dasar minimum seharihari. Oleh karena itu, Pemerintah wajib memikirkan kebijakan yang tepat untuk menurunkan garis kemiskinan di Provinsi Aceh. Kebijakan yang dikeluarkan oleh Pemerintah Aceh salah satunya adalah memperbanyak lapangan kerja yang dapat lebih banyak melakukan permintaan tenaga kerja terhadap laki-laki dibandingkan perempuan. Selain itu, pihak Perguruan Tinggi khususnya Perguruan Tinggi yang ada di Provinsi Aceh juga dapat memperbaiki mutu pendidikan agar dapat melahirkan lulusan yang siap dipakai oleh industri-industri.

\section{Kesimpulan}

Tingkat keparahan kemiskinan yang cenderung meningkat membuat Provinsi Aceh menjadi provinsi termiskin di Pulau Sumatera. Berbagai kebijakan dan dana yang mengalir diantaranya dana otsus selama satu dasawarsa belum mampu menurunkan tingkat kemiskinan di Provinisi Aceh. Selain itu, pandemik covid-19 menjadi masa sulit bagi Provinsi Aceh dalam menurunkan tingkat kemiskinan. Pandemik juga memperbesar jumlah pengangguran di Provinsi Aceh. Pengangguran terbuka terdidik universitas lakilaki berpengaruh positif terhadap garis kemiskinan, ini sesuai dengan aturan norma yang berlaku di Acehm bahwa laki-laki merupakan pencari nafkah sedangkan wanita lebih baik bekerja sebagai ibu rumah tangga. Untuk mengatasi masalah pengangguran terdidik dan kemiskinan, maka pemerintah daerah dapat menciptakan lapangan pekerjaan dengan permintaan tenaga kerja laki-laki lebih banyak dibandingkan wanita. Selain itu, peningkatan mutu untuk perguruan tinggi khususnya perguruan tinggi di Provinsi Aceh agar dapat menghasilkan lulusan yang siap terjun ke dunia kerja.

\section{Daftar Pustaka}

Ananto, E.A., Darma, T.S., Ridwan, N.M. and Rizaldi, A. (2020), "Satu Dasawarsa Otsus Aceh Tahun Anggaran 2008-2018", Pusat Kajian Akuntabilitas Keuangan Negara Badan Keahlian DPR RI, pp. 119.

Astina, C. (2019), "Perpesktif Gender Pada Masyarakat Kota Banda Aceh", Lentera, Vol. 1 No. 2, pp. 155-169.

Fitri and Junaidi. (2016), "Pengaruh pendidikan , upah dan kesempatan kerja terhadap pengangguran terdidik di Provinsi Jambi", E-Jurnal Ekonomi Sumberdaya Dan Lingkungan, Vol. 5 No. 1, pp. 26-32.

ILO. (2003), International Training Compendium on Labour Statistics.

Kementerian Ketenagakerjaan RI. (2021), "Kliping Berita Ketenagakerjaan 1 April 2021", Biro Hubungan Masyarakat, Kementerian Ketenagakerjaan RI, No. April, pp. 1-113.

Kim, J. (2018), "Analysis on the Increase in Unemployment Rates Since 2014", Http://Www.Kdi.Re.Kr/Kdi_eng/Publication /Other_article.Jsp?Pub_no=15884\&art_no $=3009 \& \mathrm{mcd}=002007$ Video, pp. 0-12.

Nurwati, N. (2008), "Kemiskinan: Model Pengukuran , Permasalahan dan Alternatif Kebijakan", Jurnal Kependudukan Padjadjaran, Vol. 10 No. 1, pp. 1-11.

Permatasari, E.O., Nasuha, F. and Prawirosastro, C.L. (2021), "Modeling The Level Of Open Unemployment In Central Java With Multivariate Adaptive Regression Spliner (MARS) Approach", International Journal of ASRO, Vol. 12 No. 01, pp. 66-74.

Prasanti, T.A., Wuryandari, T. and Rusgiyono, A. (2015), "Aplikasi Regresi Data Panel Untuk Pemodelan Tingkat Pengangguran 
Terbuka Kabupaten/Kota di Provinsi Jawa Tengah", JURNAL GAUSSIAN, Vol. 4 No. 2001, pp. 687-696.

Sari, A.K. (2013), "Analisis Pengaruh Tingkat Pendidikan, Pertumbuhan Ekonomi dan Upah terhadap Pengangguran Terdidik di Sumatera Barat", Jurnal Ekonomi Pembangunan, Vol. 1 No. 2, pp. 1-8.

Soleh, A. (2018), "Analisis dan Strategi Pengentasan Kemiskinan Di Provinsi Jambi", Jurnal IImiah Ekonomi Dan Bisnis, Vol. 9 No. 1, pp. 79-90.

Swaramarinda, D.R. (2014), "Analisis Dampak Pengangguran Terhadap Kemiskinan Di DKI JAKARTA", Jurnal Pendidikan Ekonomi Dan Bisnis (JPEB), Vol. 2 No. 2, pp. 63-70.

Yacoub, Y. (2012), "Pengaruh Tingkat Pengangguran terhadap Tingkat Kemiskinan Kabupaten / Kota di Provinsi Kalimantan Barat", Jurnal EKSOS, Vol. 8 No. 3, pp. 176-185. 